\title{
Loan Loss Provisions, Income Smooth, Signaling, Capital Management and Pro-Cyclicality. Empirical Evidence from Mozambique's Commercial Banks
}

\author{
Tito Tomas Siueia ${ }^{1} \&$ Jianling Wang ${ }^{1}$ \\ ${ }^{1}$ Department of Accounting and Finance, School of Management, Xi'an Jiaotong University, Xi'an - Shaanxi, \\ China \\ Correspondence: Tito Tomas Siueia, Ph.D. Student of School of Management, Department of Accounting and \\ Finance, Xi'an Jiaotong University, Xi'an, Shaanxi 710049, China. Tel: 86-156-91782-450. E-mail: \\ tsiueia@gmail.com or tsiueia@yahoo.com
}

Received: August 31, 2017

Accepted: September 22, 2017

Online Published: October 1, 2017

doi:10.5539/ijef.v9n11p48

URL: https://doi.org/10.5539/ijef.v9n11p48

\begin{abstract}
The aim of this study is to provide the first empirical evidence of income smoothing, capital management, signaling, and pro-cyclical behavior through loan loss provisions (LLP) for Mozambican commercial Banks, an example of the under-developed country. A second goal is to understand the bank lending behavior during the Mozambique's hidden public debt crisis. The sample consists of all commercial banks observed during 2010-2016. We provide strong evidence that Mozambican commercial banks are pro-cyclical through LLP and these banks engage in income smoothing activity. However, for capital management activity and signaling behavior, we provide insignificant evidence to support these hypotheses among Mozambican commercial banks via LLP. Also, the result indicates that Mozambique's hidden public debt crisis, the commercial banks put aside more provisions.
\end{abstract}

Keywords: Loan Loss Provisions (LLP), income smoothing, capital management, signaling, Pro-Cyclical, Mozambican Banks, hidden public debt crisis

\section{Introduction}

During the period from 2015 to 2016, the Mozambican banking industry was significantly affected by the hidden public debt crisis: bad loans piled up, both reducing revenues and increasing loan loss provisions (See Figure 1), which led to further revenue losses, one commercial bank went bankrupt and another commercial bank was intervened by the central bank to avoid its bankruptcy. Given the Mozambican hidden public debt crisis from investors between 2013 and 2014, we found a better time to make an empirical study of the dangers of betting on emerging markets. Thus, our interest in conducting research on the Mozambican banking sector. Taking into account the arguments of Lobo (2017) the banking sector is vital for a country's domestic economic and financial operations and given the high level of information asymmetry and the high degree of information uncertainty can increase opportunities earnings management. It is an ideal scenario to test the implications of discretionary reporting choices for risk-taking and financial stability.

\subsection{Introduce the Problem}

A large strand of literature shows that loan loss provisions (LLPs) are the main tool for earnings management, signaling and capital management in the banking sector. In addition, prior studies in the banking literature associated the pro-cyclical behavior with the banking activity.

Following the prior study, pro-cyclicality occurs when managers reduce their provisions during good times and increase them in bad times. The pro- cyclicality's consequence is that it may trigger a credit crunch that could worsen the economic recession, (Kanagaretnam et al., 2009). Income smoothing can be defined as a kind of earnings management. It occurs when managers use LLP to smooth income upward by underestimating expected loan losses to lower net income, and in contrast, managers may smoothing income downward by overestimating expected loan losses to lower net income, (Lobo \& Yang, 2001). Capital management occurs when the bank managers use the loan loss provisions to achieve regulatory capital targets constraining their banks capital, (Lobo \& Yang, 2001). Signaling happens when managers increasing current LLP to signal the future potential earnings 
power of the bank, (Lobo \& Yang, 2001).

Several researchers in the banking literature associates the LLP with the pro-cyclicality such as: Bikker and Hu (2002); Laeven and Majnoni (2003); Perez et al. (2006); Floro (2010); Packer and Zhu (2012); Ozili (2015); Adziz et al. (2015); Skala (2015); Fernando and Ekanayaka (2015); Caporale et al. (2015); Olszak et al. (2016) and Morris et al. (2016).

In addition, the researchers investigated the use of LLP to smoothing income and documents different findings such as Kanagaretnam et al. (2004); Anandarajan et al. (2007); Perez et al. (2008); Fonseca and Gonzalez (2008) and Kanagaretnam et al. (2010). Also, recent banking literature provide evidence of using LLP to income smoothing such as Leventis et al. (2012); El Sood (2012); Kilic et al. (2013); Curcio and Hasan (2013); Bouvatier at al. (2014); Olson and Zoubi (2014); Cucinelli (2015); Bryce et al. (2015); Adziz et al. (2015); Fernando and Ekanayaka (2015); Skala (2015); Caporale et al. (2015), Ozili (2015); Olszak et al. (2016); Morris et al. (2016) and Curcio et al. (2017).

Existing studies also highlight that LLP is associated with the capital management (Ahmed et al., 1999; Wall \& Koch, 2000; Anandarajan et al., 2007; Bouvatier \& Lepetit, 2008 and Perez et al., 2008). The recent baking literature is Dong et al. (2012); Leventies et al. (2012); Curcio and Hasan (2013); Bouvatier at al. (2014); Ozili (2015); Adziz et al. (2015); Fernando and Ekanayaka (2015) and Caporale et al. (2015).

In additional banking literature also explore the use of discretion over LLP for signaling issue such as Wahlen (1994); Kanagaretnam et al. (2005); Anandarajan et al. (2007); Perez et al. (2008) and Bouvatier and Lepetit (2008). And, recently Leventis et al. (2012); Curcio and Hasan (2013); Olson and Zoubi (2014); Ozili (2015); Adziz et al. (2015); Fernando and Ekanayaka (2015); Caporale et al. (2015) and Morris et al. (2016).

Overall, of these studies employ the European bank's data, the U.S. banks data, the Asian bank's data and African banks, particularly for developed economies and evidence from under-developed economies remains rare, in a special case for Mozambican commercial banks the study does not exist.

Motivated by Mozambican hidden public debt crisis we examine the evidence of income smoothing, capital management, signaling, and pro-cyclical behavior through LLP of Mozambican commercial banks over a period from 2010-2016.

According to prior banking literature, we summarize our hypotheses as following:

H1: Mozambican commercial banks exhibit pro-cyclical behavior through loan loss provisions.

H2: Mozambican commercial banks do smooth income through loan loss provisions.

H3: Mozambican commercial banks manage capital through loan loss provisions.

H4: Mozambican commercial banks engage in signaling through loan loss provisions. And

H5: Mozambican commercial banks are negatively associated with Loan Loss Provisions (LLP).

The main findings of our analysis are as follows. Firstly, we found a significant and negative association between LLP and GDP growth implying that Mozambican commercials banks are pro-cyclical. Secondly, we found a positive and statistically significant association between income smoothing and LLP suggesting that the Mozambican commercial banks are using LLP to smooth income. Thirdly, we find that LLP is also insignificantly affected by capital management activity. Fourthly, for signaling hypothesis, we did not find concrete evidence to support the existence of this activity in Mozambican commercial banks. Finally, we found concrete evidence to lend support that a bank's size has an impact on the level of LLP.

Our study differs from previous studies in several ways. First, this is the first evidence about Mozambican commercial banks. Second, this study examines whether pro-cyclical behavior, income smoothing activity, capital management activity, and signaling behavior does exist through LLP in Mozambican commercial banks. Finally, the study controls for the effect of Mozambican hidden public debt crisis on loan loss provisions of commercial banks and effect of bank size on LLP.

Our study makes a great contribution to the literature, expanding the existing accounting and financial literature on the determinants of LLP and pro-cyclical behavior showing that the macroeconomic policies issued by the government affect the course of activities in the banking sector concretely in the commercial banks for the under-developed country.

\subsection{Country Background}

The Republic of Mozambique is country located in the southeastern region of the African continent. Mozambique was one of the economic giants' in Africa between 2010 and 2015, with an average annual GDP 
growth rate of about $6 \%-8 \%$ and, attracted foreign direct investments, in the areas of natural coal, natural gas, titanium and in the hydroelectric subsectors of the economy. On the other hand, according to the IMF, Mozambique was the African country with the highest growth in external public debt between 2011 and 2013 with increases of $30 \%$ a year.

In April 2015, it was learned that the Mozambican government hid from the investors 4 loans of about 1.16 Billion Dollars ceded to Mozambican companies. In the case of Mozambican tuna company (EMATUM). "Proindico" - a company linked to the interior and defense ministries, the Mozambican secret services, MEM Mozambique set Management a state firm set up to build a shipyard in "Pemba city" and the interior ministry. All these loans were granted with sovereign guarantees from the Mozambican Government. The companies lent the money between 2013 to 2014 from Russian bank VTB and Credit Suisse, a Swiss financial service multinational. Due to the lack of transparency in the process, the IMF suspended the assistance to Mozambique after disclosure of this debt to investors, leaving Mozambique in a situation of financial instability, considering that FIM aid represents about 10\% of the State budget (source: WSJ - Wall Street Journal, AIM - Mozambique Information Agency, CIP - Center for Public Intrigue, DW Africa).

Consequently, during this period, the Mozambican banking industry was significantly affected by the public hidden debt crisis. Bad loans piled up; both reducing revenues and increasing LLP (See Figure 1); which led to further revenue losses; one commercial bank went bankrupt, and another one, received support by way of intervention from the central bank of Mozambique to avoid its bankruptcy.

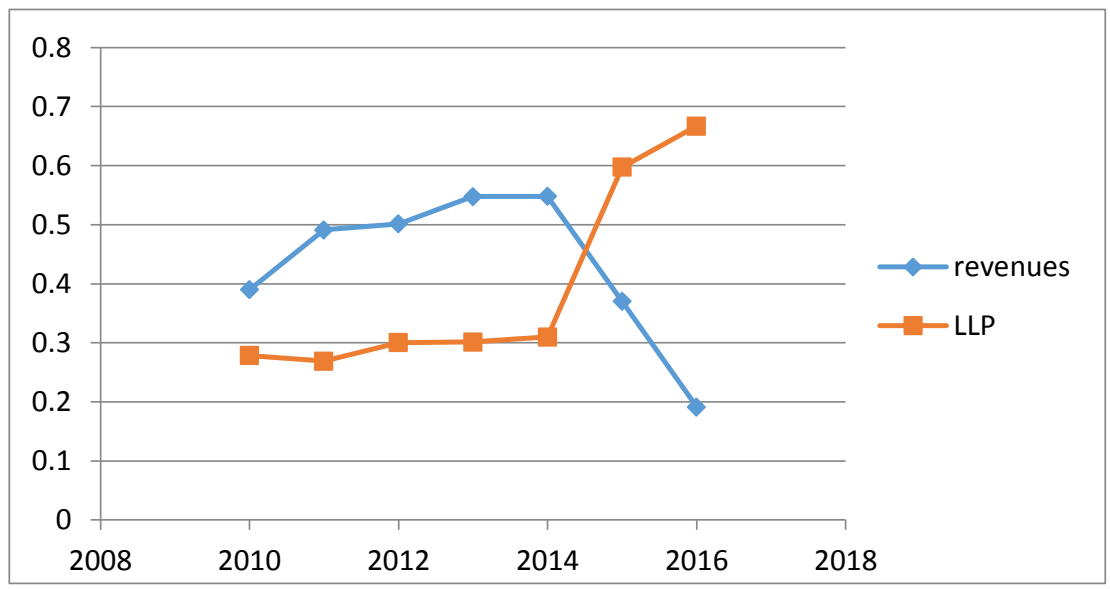

Figure 1. Loan loss provisions and bank revenues, between periods of 2010-2016.

Source: researcher's calculations using data from Bank of Mozambique.

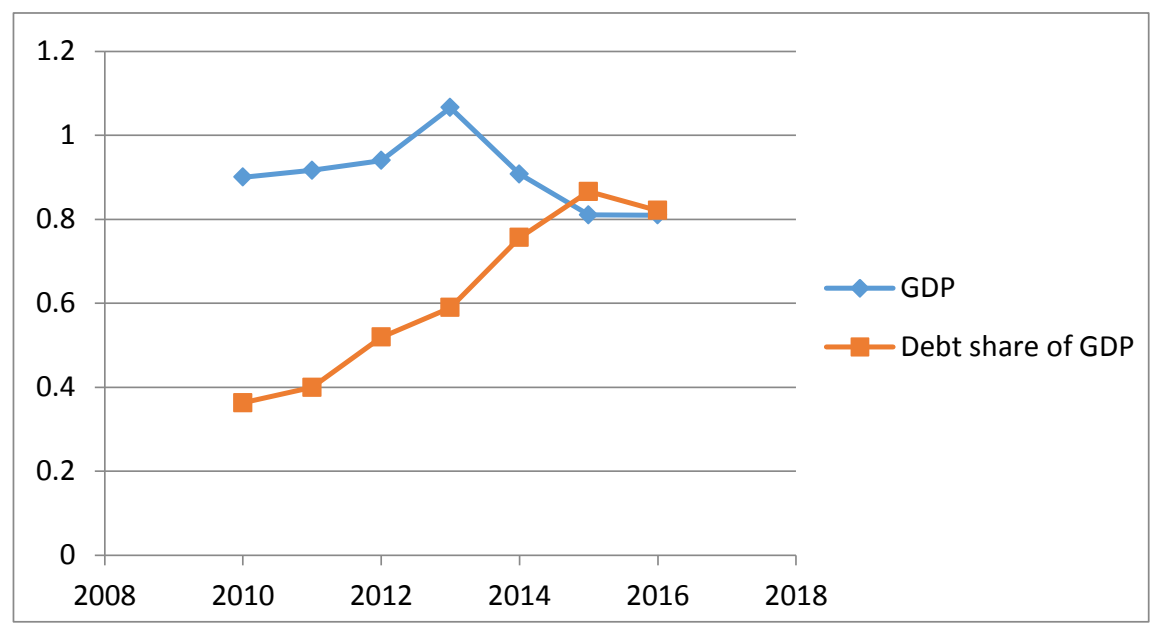

Figure 2. Gross Domestic Product (GDP) and debit share of GDP, between periods of 2010-2016

Source: IMF. 


\subsection{Relevant Related Literature and Hypotheses}

\subsubsection{LLP and Pro-Cyclicality Behavior}

The available literature argues that there is a link between business cycles and bank lending activity. In addition, it suggests that pro-cyclicality occurs when during the bad times, the bank managers increase the provisions (LLP) and decrease bank lending in order not to adversely affect the bank's capital and, during the good times, they reduce the provisions (LLP).

To support this point of views we highlight some studies, Floro (2010) using a sample of Philippine financial intermediaries within 2001-2009, provided evidence to lend support pro-cyclical hypothesis through loan loss provisions. However, it was observed that such association is influenced in a non-linear way by bank capitalization. Ozili (2015) during the period of 2002-2013 examines the motivations and the behavior of LLP in relation to the business cycle using a sample of Nigerian commercial banks, which provided strong evidence for pro-cyclical behavior during the study period. Skala (2015) investigate the impact of bank earnings cycle and the business cycle in a cross-countries study using a sample of 244 commercial banks in 11 Central European countries over 2004 to 2012, documents that the provisions are pro-cyclical with respect to national business cycles and the banks are engaged in smoothing activity via LLP. Olszak et al. (2016) examined the factors that affect the pro-cyclicality of LLP among the Poland commercial bank, during the period of 2000-2012, the result shows that LLP are pro-cyclical, and the Poland cooperative banks are less pro-cyclical than the commercial banks. Morris et al. (2016) investigate the impact of economic determinants during the international financial crisis, using a sample of 5187 US bank-quarter observations over the period from 2006 to 2010. They provide strong empirical evidence that pro-cyclical behavior is especially pronounced during the international financial crisis (2009-2010) and also found evidence to support smoothing activity and signaling behavior via LLP.

On the other hand, some research finds a mixed result as Packer and Zhu (2012), investigate the determinant of LLP among 240 Asian banks over the period 2000 to 2009, the results provide evidence to lend support to the pro-cyclical hypothesis through LLP among Japanese banks; but countercyclical among banks in India.

Additional some research does not support the pro-cyclical behavior such as Caporale et al. (2015) find evidence that in Italian banks, LLP is driven mainly by non-discretionary components during the economic recession period (2008-2012). To resume, they provide evidence to lend support counter-cyclical hypothesis through loan loss provisions. Adzis et al. (2015) using a sample of Malaysian commercial banks during the period of 2002-2012, did not have enough evidence to support the pro-cyclical hypotheses though LLP.

Overall, the previous study documents more negative evidence of pro-cyclical behavior via LLP. We hypothesize as follows:

\section{H1: Mozambican commercial banks exhibit pro-cyclical behavior through loan loss provisions.}

\subsubsection{LLP and Income Smoothing Hypothesis}

Previous studies have shown that income smoothing can be defined as a kind of earnings management. It happens when managers use LLP to smooth income upward by underestimating predicted loan losses to lower net income, and in contrast, managers may be smoothing income downward by overestimating predicted loan losses to lower net income. Benston and Wall (2005) argue that income smoothing is the type of manipulation activity used by the manager to adjust the earnings. They use income smoothing to reduce the information asymmetry.

To support this point of views we highlight some studies: Kanagaretnam et al. (2010) in their multi-country study using a sample of 29 countries between the periods from 1993 to 2006 to investigate the relation between auditor reputation and earnings management in banks sector; they provide evidence that managers do income smoothing through LLP. In contrast, Perez et al. (2008) examine the impact of earnings management and capital management through LLP in Spanish banks and provide evidence for income smoothing activities in Spanish banks from 1986 to 2002 using 142 banks. However, they did not find evidence for capital management activity.

In addition, recently some researchers provide evidence for smoothing activity. Leventies et al. (2012), examined the influence of IFRS on earnings management and capital management, using a sample of 91 Union Europe listed commercial banks during period 1999-2008 and provided evidence that banks engage in income smoothing activity, but after implementation of IFRS in 2005 the income smoothing activity decline relatively to the pre-IFRS period. However, they did not find concrete evidence for capital management activity in both pre and post-IFRS regimes. El Sood (2012) examined the income smoothing through LLP in 878 US banks over 2001 to 2009; they provided strong evidence for income smoothing activity during the international financial crisis. And Kilic et al. (2013), examined the impact of SFAS 133 on the reporting behavior of US commercial 
banks, they provide strong evidence that US commercial banks do smoothing activity through LLP. Adzis et Al. (2015) using a sample of Malaysian 15 commercial banks during the period of 2002-2012, provide empirical evidence that Malaysian commercial banks engage in income smoothing activity during the period of study. In summary, they provided evidence to lend support income smoothing hypothesis through LLP. Ozili (2015) examines the motivations and the behavior of LLP in relative to the business cycle using of 10 Nigerian commercial banks during the period of 2002-2013, provided empirical evidence that Nigerian commercial banks engage in income smoothing activity, supporting the income smoothing hypothesis through loan loss provisions. Skala (2015) and Morris et al. (2016) in the studies reported in section 2.1 above provide strong empirical evidence to support smoothing activity via LLP. Also, Curcio et al. (2017) examined the impact of discretionary via LLP in European banks during the international financial crisis, and provided strong empirical evidence to support income smoothing hypothesis through LLP, they did not find any difference between listed and unlisted banks behavior. The smoothing activity is more pronounced only in 2011 .

In contrast, some study found no evidence of smoothing activity via LLP such as Anandarajan et al. (2007) examined earnings management, capital management and signaling through Bank LLP using a data of 50 Australian commercials banks over the period of 1991 to 2001. They provided evidence that Australian commercial banks use LLP to earnings management. However, they did not provide evidence for capital management activity. Caporale et al. (2015) examined the determinant of LLP using a sample of 400 Italian banks during the period of 2001-2012 and was revealed that in Italian banks, LLP is not driven by discretionary components (income smoothing). In summary, they provided no evidence that to lend support income smoothing hypothesis through LLP. Bryce et al (2015) examined the income-smoothing, capital manage and cyclical management hypotheses on Vietnamese banks during the period 2007-2014, and did not find enough evidence that Vietnamese banks engage in income smoothing activity, but when incorporated the X-efficiency estimates in the model the banks did not exhibit the income smoothing activity.

The previous research provides a mixed result, however, it is documented more evidence of smoothing activity through LLP. Therefore, we hypothesize as follows:

\section{H2 = Mozambican commercial banks do smooth income through loan loss provisions.}

\subsubsection{LLP and Capital Management}

Capital management occurs when capital becomes constrained; the bank's managers will use discretionary additions to achieve regulatory capital targets. Chang et al. (2008) argue that the capital ratio is an important indicator that reflects the bank's risk, playing an important role in showing the bank's ability to support the current capital structure and denoting the undetectable default risk.

In order to support capital management hypotheses we highlight some studies, for example Dong et al. (2012) using a sample of 14 China commercial banks during period 2001-2009 found evidence to lend to support the capital management hypothesis in China banks. The finding shows that when the bank capital adequacy is low, the managers set aside more LLP to increase bank capital in order to satisfy the regulatory requirements. As reported above in 1.3.2 section Ozili (2015) provided empirical evidence for capital management activity for Nigerian commercial banks during the period of 2002-2013.

In contrast, Anandarajan et al. (2007) in a study documented in section 1.3.2 above did not provide empirical evidence for capital management activity for Australian commercial banks. Perez et al. (2008); provided no evidence to lend support capital management hypothesis using LLP to manage regulatory capital in Spanish banks, as documented in section 1.3.2 above. And recently, Leventies et al. (2012), Adzis et al. (2015), Caporale et al. (2015) in their studies documented in sections 1.3.1 and 1.3.2 above did not find concrete evidence for capital management activity through LLP.

Overall, the banking literature provides mixed evidence of capital management behavior. We predict a positive relation between LLP and capital management. Therefore, we hypothesize as follows:

\section{H3 = Mozambican commercial banks manage capital through loan loss provisions.}

\subsubsection{LLP and Signaling}

LLP is used to signal financial strength. Specifically Signaling happens when managers expect to signal the financial strength of the banking sector to reduce information asymmetry. Wahlen (1994) argue that investors interpret abnormal provisions as a signal of good economic news than as a signal of bad economic news. Kanagaretnam et al., (2005) argue that undervalued banks use LLP to signal private information about a bank's future performance. 
We highlight some empirical evidence to support the signaling hypothesis via LLP. Curcio and Hasan (2013) investigated the impact of earnings management, capital management, and signaling activity via LLP among EU banks and non-EU credit institutions during period 1996-2006. The study provided evidence that EA banks do not engage in signaling activity, however, the non-EU banks use LLP as a tool to convey information to investors. Olson and Zoubi (2014) investigated the impact of determinants of the LLP and Allowance for Loan Losses (ALL) of banks, using a sample of 75 banks of the Middle East and North African over the period 2000-2008. The study provided empirical evidence to lend support signaling hypotheses via LLP and ALL. Morris et al. (2016) in the study documented in sections 1.3.1 and 1.3.2 above found concrete evidence to support that US-banks engages in signaling activity through LLP.

In contrast Ahmed et al. (1999); Anandarajan et al. (2007); Bouvatier and Lepetit (2008), Perez et al. (2008); Leventies et al. (2012), Adzis et al. (2015), Caporale et al. (2015) in their studies documented in sections 1.3.1 and 1.3.2 above did not find concrete evidence to support that banks engage in signaling activity through LLP.

Therefore, the evidence of this linkage is mixed. We hypothesis as follows:

\section{H4 = Mozambican commercial banks engage in signaling through loan loss provisions.}

\subsubsection{LLP and Bank Size}

The previous literature argues that there is a link between income smoothing activity and Bank size and bank size is an important tool of risk-taking. Laeven et al. (2014) argue that large banks have a more fragile business model than small banks.

We highlight some empirical evidence to support this hypothesis. Carporale et al. (2015) in the study documented in sections 2.1 and 2.2 above argue that bank size effect in income smoothing activity. Olszak et al. (2016) found evidence to support bank size through LLP implying that large banks are more negatively related to the business cycle, especially for large banks that consolidated their financial statements. Jin et al. (2016) examined the impact of discretion and how it relates to bank stability and bank risk-taking among US commercial bank, over a period of 2000 to 2008, provided strong evidence that banks sizes are determinants for bank performance. Other researchers do support the Bank size hypotheses through LLP, such as Fonseca and Gonzalez (2008); Curcio and Hasan (2013); Caporale et al. (2015); Ozili (2015).

Following this prior study, we expect a negative relation between bank-size and LLP. We include an interactive dummy variable to indicate the period of Mozambican hidden debt crisis. Therefore, we hypothesize as follows:

\section{H5: Mozambican commercial banks are negatively associated with Loan Loss Provisions (LLP).}

The rest of this paper is organized as follows. Section 2 explains the research design, introduces the data and explains the sample. Section 3 summarizes the main results and discussion, and finally, Section 4 concludes.

\section{Method}

\subsection{Data and Sample}

This study uses bank dataset extracted from the financial statement and balance sheets of the selected commercial banks operating in Mozambique. The bank's financial data was downloaded from the Bank of Mozambique (Central Bank of Mozambique) website.

The macroeconomic dataset, Growth Domestic Product (GDP), were extracted from the National Institute of Statistics of Mozambique (INE) website and we supplement these data with macroeconomics data from the International Monetary Fund (IMF) website.

In Mozambique by the end of 2016, the banking system comprised of 19 banks, where the majority are foreign commercial banks. Because the sample is small and we did not want to lose further observations, we did not exclude foreign commercial banks and we did not consider the effect of the outliers in the regressions, so we did not exclude the data in the upper and lower bounds of the distributions. A final sample of 19 banks for a 7 -year period, from 2010-2016, which includes the Mozambican hidden public debt crisis in 2015-2016, which gives 133 bank-year observations.

\subsection{Estimation Methods}

\subsubsection{Basic Model}

There is a huge literature on the linkages between LLP, income smoothing, regulatory capital, signaling and business cycles. To test our hypotheses we follow a similar approach applied by Bouvatier et al. (2014), Skala, (2015) and Caporale et al. (2015). The basic model is as follows: 


$$
\begin{array}{r}
L L P_{i, t}=\lambda_{0}+\lambda_{2} N P L_{i, t}+\lambda_{3} \Delta N P L_{i, t}+\lambda_{4} \Delta \operatorname{Loan}_{i, t}+\lambda_{5} \Delta G D P_{t}+\lambda_{6} C r i_{t}+\lambda_{7} \Delta G D P_{t} * C r i s t+\lambda_{8} I S m_{i, t}+ \\
\lambda_{9} \text { Cap }_{i, t}+\theta i,+\varepsilon_{i, t}
\end{array}
$$

In order to carry out robustness checks on our baseline model we applied a dynamic specification to equation 1 by introducing the lagged dependent variable as shown in equation 2 below:

$$
\begin{gathered}
L L P_{i, t}=\lambda_{0}+\lambda_{1} L L P_{i, t-1}+\lambda_{2} N P L_{i, t}+\lambda_{3} \Delta N P L_{i, t}+\lambda_{4} \Delta \operatorname{Loan}_{i, t}+\lambda_{5} \Delta G D P_{t}+\lambda_{6} \text { Cris }_{t} \\
+\lambda_{7} \Delta G D P_{t}^{*}{ }^{*} \text { Crist }+\lambda_{8} I_{S m_{i, t}}+\lambda_{9} \operatorname{Cap}_{i, t}+\theta i,+\varepsilon_{i, t}
\end{gathered}
$$

Where: $\theta_{\mathrm{i}}$ is unobservable bank specific effects as bank corporate culture. And $\varepsilon_{\mathrm{i}, \mathrm{t}}$ are white's robust error regression coefficient. All variables used in our study are defined in section 2.3.

In this paper, we apply both the Arellano and Bover (2005) and Blundell and Bond (1998) the generalized method of moments (GMM), applying two-step estimator robust to heteroscedasticity, including the fixed effects of the specification. The GMM tools are singly used for the lagged dependent variable $\left(\operatorname{LLP}_{\mathrm{i}, \mathrm{t}-1}\right)$, whereas the other variables are treated as strictly exogenous. Additionally, a robust AR(2) test was performed to verify the absence of second-order serial correlation in the first-difference residuals. Also the robust the Hansen test was carried out to check the validity of our instrument. We also tested the multi-collinearity problems by computing the correlation matrix and the VIF (variance inflation factors). (Similar to Bouvatier et al., 2014; Skala, 2015 and Caporale et al., 2015 study).

\subsubsection{Pro-cyclical Model}

$L L P_{i, t}=\lambda_{0}+\lambda_{1} L L P_{i, t-1}+\lambda_{2} N P L_{i, t}+\lambda_{3} \Delta N P L_{i, t}+\lambda_{4} \Delta \operatorname{Loan}_{i, t}+\lambda_{5} \Delta G D P_{t}+\lambda_{6} \operatorname{Cris}_{t}+\lambda_{7} \Delta G D P_{t}^{*}$ Crist $+\theta i,+\varepsilon_{i, t}(1.1)$

First, we use equation 1.1 but we did not include the lagged dependent variable $\left(\operatorname{LLP}_{\mathrm{i}, \mathrm{t}-1}\right)$, to examine the pro-cyclical hypotheses (H1). All variables are defined in section 2.3 below. Following the previous study, we expected a negative association between Loan Loss Provision (LLP) and GDP growth rate implying that coefficient $\lambda_{5}$ will be negative and statistically significant. On another hand, the coefficient $\lambda_{6}$ on CRIS variables it expected a negative signal, as well as the coefficient $\lambda_{7}$ on the interactive dummy, $\Delta \mathrm{GDP}_{t}{ }^{*} \mathrm{Cris}_{\mathrm{t}}$, it expected a negative signal, to indicate the pro-cyclical behavior in our model and to support our hypothesis H1. (Packer \& Zhu, 2012; Bouvatier et al., 2014; Ozili, 2015; Olszak et al., 2016).

\subsubsection{Income Smoothing Model}

To study the effect of income smoothing through Loan Loss Provisions (LLP) we run the model 1.2 shown below, it was excluded the lagged dependent variable $\left(\operatorname{LLP}_{\mathrm{i}, \mathrm{t}-1}\right)$ :

$$
\begin{aligned}
L L P_{i, t}=\lambda_{0}+\lambda_{1} L L P_{i, t-1}+ & \lambda_{2} N P L_{i, t}+\lambda_{3} \Delta N P L_{i, t}+\lambda_{4} \Delta \operatorname{Loan}_{i, t}+\lambda_{5} \Delta G D P_{t}+\lambda_{6} \text { Cris }_{t}+\lambda_{7} \Delta G D P_{t} * \text { Cris }_{t}+\lambda_{8} I S m_{i, t} \\
& +\lambda_{9} I_{S m_{i, t}} * \text { Cris }_{t}+\lambda_{10} \text { ISm }_{i, t} * \text { NonCris }_{t}+\theta i,+\varepsilon_{i, t}
\end{aligned}
$$

All variables are defined in section 2.3 below. Following the previous study we used $\lambda 8$ coefficient to measure the impact of income smoothing activity in our model, we expected $\lambda 8$ coefficient to be positive and statistically significant to support the income smoothing hypotheses implying that the bank managers are engaged in income smoothing activity through LLP, otherwise, we reject the hypothesis. (Bouvatier et al., 2014; Ozili, 2015; Caporale et al., 2015 and Olszak et al., 2016). We introduced the interactive dummy variable to measure the impact of income smoothing activity during the Mozambique hidden debt crisis, which was equal to one for a period of 2015-2016, zero otherwise. The coefficients $\lambda_{9}$ and $\lambda_{10}$ will tell us about the sensitivity of income smoothing activity during the crisis and non-crisis period.

\subsubsection{Capital Manage Model}

To investigate the effects of capital managed through Loan Loss Provisions (LLP) we run the model 1.3 shown below, but we did not include the lagged dependent variable $\left(\operatorname{LLP}_{\mathrm{i}, \mathrm{t}-1}\right)$ :

$$
\begin{gathered}
L L P i, t=\lambda_{0}+\lambda_{1} L L P_{i, t-1}+\lambda_{2} N P L_{i, t}+\lambda_{3} \Delta N P L_{i, t}+\lambda_{4} \Delta \operatorname{Loan}_{i, t}+\lambda_{5} \Delta G D P_{t}+\lambda_{6} \operatorname{Cris}_{t}+\lambda_{7} \Delta G D P_{t}^{*} \text { Cris }_{t}+\lambda_{8} \text { ISm }_{i, t} \\
+\lambda_{9} \operatorname{Cap}_{i, t}+\lambda_{10} \text { Cap }_{i, t} * \text { Cris }_{t}+\lambda_{11} \text { Cap }_{i, t}{ }^{*} \text { NonCris }_{t}+\theta_{i}+\varepsilon_{i, t}
\end{gathered}
$$

In equation 1.3, all variables are defined in section 2.2.1 above. Following the previous study, we used $\lambda_{9}$ coefficient to measure the impact of the capital ratio in our model, and we expected $\lambda_{9}$ coefficient to be positive and statistically significant to support the capital management hypotheses implying that the bank managers are engaged in manipulation activity through LLP, otherwise we reject the hypothesis. The coefficients $\lambda_{10}$ and $\lambda_{11}$ will tell us about the sensitivity of capital management behavior during the crisis and non-crisis period. (Bouvatier et al., 2014; Ozili, 2015; Caporale et al., 2015 and Olszak et al., 2016).

\subsubsection{Signaling Model}

To investigate the effects of signaling through Loan Loss Provisions (LLP) we run the model 1.4 shown below, 
but it was excluded the lagged dependent variable $\left(\operatorname{LLP}_{\mathrm{i},-1-1}\right)$ :

$$
\begin{gathered}
L L P_{i, t}=\lambda_{0}+\lambda_{1} L L P_{i, t-1}+\lambda_{2} N P L_{i, t}+\lambda_{3} \Delta N P L_{i, t}+\lambda_{4} \Delta \operatorname{Loan}_{i, t}+\lambda_{5} \Delta G D P_{t}+\lambda_{6} \operatorname{Cris}_{t}+\lambda_{7} \Delta G D P_{t} * \operatorname{Cris}_{t}+\lambda_{8} I \operatorname{Sm}_{i, t} \\
+\lambda_{9} \operatorname{CaP}_{i, t}+\lambda_{10} \operatorname{Sig}_{i, t}+\theta_{i}+\varepsilon_{i, t}
\end{gathered}
$$

In equation 1.4, all variables are defined in section 2.3 below, we used $\lambda_{10}$ coefficient to measure the impact of signaling in our model. We predicted that the coefficient $\lambda_{10}$ will be positive to support our hypothesis. Following previous research, this coefficient presents mixed signal. (Ozili, 2015; Caporale et al., 2015 and Olszak et al., 2016).

\subsubsection{Bank-Size Model}

To investigate the effects of size in income behavior we run the model 1.5 shown below, we include a dummy variable for the income-smoothing hypothesis, but we did not include the lagged dependent variable $\left(\operatorname{LLP}_{\mathrm{i}, t-1}\right)$ :

$$
\begin{gathered}
L L P_{i, t}=\lambda_{0}+\lambda_{1} L L P_{i, t-1}+\lambda_{2} N P L i, t+\lambda_{3} \Delta N P L_{i, t}+\lambda_{4} \Delta \text { Loan }_{i, t}+\lambda_{5} \Delta G D P_{t}+\lambda_{6} \text { Cris }_{t}+\lambda_{7} \Delta G D P_{t} * \text { Cris }_{t}+\lambda_{8} \text { Size }_{i, t} \\
+\lambda_{9} \text { Size }_{i, t} * \text { Cris }_{t}+\lambda_{10} \text { Size }_{i, t} * \text { NonCris }_{t}+\lambda_{11} \text { Cap }_{i, t}+\theta_{i}+\varepsilon_{i, t}
\end{gathered}
$$

In equation 1.5 all variables are defined in section 2.3 below, we used $\lambda_{8}$ coefficient to measure the bank size in our model, and we predicted that the coefficient $\lambda_{8}$ will be positive (negative) to support our hypothesis. Following previous research, this coefficient presents mixed signal. (Ozili, 2015; Caprpole et al., 2015 and Olszak et al., 2016). In order to investigate the effects of size in income behavior during the Mozambique hidden debt crisis, we included the interactive dummy variable CRIS which was equal to one for the period of 2015-2016 and zero otherwise.

\subsection{Variable Explanation}

\subsubsection{Dependent Variable}

$\operatorname{LLP}_{\mathrm{i}, \mathrm{t}}=$ The ratio of Loan loss provisions (LLP) to total assets for bank $\mathrm{i}$ and time $\mathrm{t}$.

Previous banking literature (Anandarajan et al., 2007; Leventis et al., 2012; Packer \& Zhu, 2012; Curcio \& Hasan, 2013; Bouvatier et al., 2014; Ozili, 2015 and Olszak et al., 2016) argues that LLP as dependent variables to examine the evidence of management discretionary which are capital management, income smoothing, signaling and pro-cyclicality in the banking sector, in this case, we used LLP scaled by total asset as dependent variable in our research.

\subsubsection{Independent Variables}

$L L P_{i, t-1}=$ The ratio of beginning loan loss provision to the total asset for bank $\mathrm{i}$ and time $\mathrm{t}$, (Dong et al., 2012; Bouvatier et al., 2014 and Caporale et al., 2015).

$N P L_{i, t}=$ The ratio of non-performing loans to total loans for bank $\mathrm{i}$ and time $\mathrm{t}$.

The non-discretionary component is related to credit risk and it is made to cover expected credit losses on loans (Hasan and Wall 2004) and exhibits strong cyclicality pattern (Bikker and Metzemakers, 2005).

Following prior study (Dong et al., 2012; Bouvatier et al., 2014; Skala, 2015; Adzis et al., 2015; Caporale et al., 2015; Ozili, 2015), we include the ratio of non-performing loans to total loans $\left(\mathrm{NPL}_{\mathrm{i}, \mathrm{t}}\right)$ as an indicator of loan default, the loan loss provision will be higher if we have the higher non-performing loan. It's expected to have a positive relationship between NPL and LLP.

$\triangle N P L_{i, t}=$ Change in the ratio of non-performing loans to total loans for bank $\mathrm{i}$ and time $\mathrm{t}$.

Following previous research, the relationship between LLP and $\triangle$ NPL will be positive and statistically significant if, bank managers use some ration of LLP to cover predicted loan losses, (Fonseca \& Gonzalez, 2008 and Bouvatier \& Lepetit, 2008). Alternatively, the relationship between LLP and $\triangle$ NPL will be negative if, the bank managers do not set aside provisions to cover predicted loan losses, (Laeven \& Majnoni, 2003).

$\Delta \operatorname{Loan}_{i, t}=$ The Loan growth ratio.

We included $\Delta \operatorname{Loan}_{i, t}$ as another non-discretionary factor. This variable is used as a proxy to measure bank credit risk; the bank manages increase provision when they expect that loan will go bad. Thus, $\Delta \operatorname{Loan}_{i, t}$ is expected to have a negative relationship with LLP.

$\triangle G D P_{t}=$ the annual rate of change of Mozambican Growth Domestic Product.

This proxy was used to capture the pro-cyclicality of LLP. A positive sign indicates LLP is counter-cyclical, otherwise, the negative sign indicates LLP is pro-cyclical. This means that the relationship between $\triangle \mathrm{GDP}_{\mathrm{t}}$ and LLP will provide evidence for pro-cyclical behavior in the model. (Fonseca \& Gonzàlez 2008; Curcio \& Hasan, 
2013; Adzis et al., 2015; Caporale et al., 2015; Ozili, 2015).

Cris $_{t}=$ A dummy variable for Mozambican hidden public debt crisis (1 for years 2015-2016 and 0 otherwise). According to prior research, the international financial crisis had an impact on banking behavior (Fonseca and Gonzàles, 2008; Leventis, et al., 2012; Curcio and Hasan, 2013; Adzis et al., 2015; Caporale et al., 2015; Ozili, 2015). In the Mozambican case, we included this dummy variable in our model to investigate the impact of the recent Mozambican hidden public debt crisis (2015-2016).

$I S m_{i, t}=$ the ratio of earnings before interest, taxes, and LLP to total assets for bank $\mathrm{i}$ and time $\mathrm{t}$.

$\mathrm{ISm}_{\mathrm{i}, \mathrm{t}}$ we use this proxy to measure existence of Income smoothing activity in our model consistent with previous research (Fonseca \& Gonzàles, 2008; Leventis et al., 2012; Curcio \& Hasan, 2013; Adzis et al., 2015; Caporale et al., 2015; Ozili, 2015). The positive sign of IS $_{\mathrm{i}, \mathrm{t}}$ indicates that bank managers are involved in smoothing activity through LLP and a negative sign indicates otherwise.

$\mathrm{Cap}_{i, t}=$ the ratio of total equity to total assets for bank $\mathrm{i}$ at time $\mathrm{t}$.

$\mathrm{Cap}_{\mathrm{i}, \mathrm{t}}$ is a proxy to measure the invisible risk of default. To show the bank's ability to survive under the current capital structure. Previous study suggest that the positive sign of $\mathrm{Cap}_{\mathrm{i}, \mathrm{t}}$ indicate that bank managers have the incentive to decrease LLP and the negative sign otherwise (Fonseca \& Gonzàles, 2008; Leventis et al., 2012; Curcio \& Hasan, 2013; Adzis et al., 2015; Caporale et al., 2015; Ozili, 2015).

$\mathrm{Sig}_{i, t}=$ the one-year ahead change in earnings before tax and provisions for bank i and time $\mathrm{t}$.

Following previous study we included variable $\mathrm{Sig}_{\mathrm{i}, \mathrm{t}}$ to test the signaling hypothesis, (where $\operatorname{Sig}_{\mathrm{i}, \mathrm{t}}=\mathrm{ISm}_{\mathrm{i}, \mathrm{t}+1}-$ $\mathrm{ISm}_{\mathrm{i}, \mathrm{t}} / \mathrm{ISm}_{\mathrm{i}, \mathrm{t}}$ ), it is expected that bank managers may or may not use LLP to signal their financial strength (Adzis et al., 2015; Caporale et al., 2015; Ozili, 2015).

$S i z i_{i, t}=$ the natural logarithm of total assets for bank i and time t. It is expected to have a positive sign.

$I S m_{i, t} * \mathrm{Cris}_{t}=$ the interactive dummy variable for income smoothing hypothesis, is equal to 1 for the years 2015-2016, 0 otherwise.

$\mathrm{ISm}_{i, t}{ }^{*}$ NonCris $_{t}=$ the interactive dummy variable for income smoothing hypothesis, is equal to 1 for the years 2010-2014, 0 otherwise.

\section{Results and Discussion}

\subsection{Statistics and Correlation Matrix}

Table 1 summarizes the descriptive statistics of the main variables of interest for the object of the study. The average value for Loan Loss Provisions (LLP) is close to $0.80 \%$, whilst bad loans represent about $6.1 \%$ of total loans (NPL). Change in the ratio of non-performing loans to total loans for bank i and time t ( $\triangle \mathrm{NPL}$ ) is $9.2 \%$. Loan growth ( $\triangle$ Loan) of banks represents about $5.1 \%$ of total assets. GDP is $4.86 \%$. Cris is $34.6 \%$. On average the ratio of earnings before interest, taxes, and LLP to total assets for bank i and time $t$ (ISm) is $1.7 \%$. The capital (Cap) is $1.3 \%$ finally, the Size $8.33 \%$.

Table 1. Statistics of main variable

\begin{tabular}{llllll}
\hline Variable & Obs & Mean & Min & Max & Std Dev. \\
\hline LLP & 133 & 0.008 & -0.201 & 0.483 & 0.031 \\
LLPi,t-1 & 133 & 0.022 & -0.101 & 0.398 & 0.058 \\
NPL & 133 & 0.061 & 0.018 & 0.041 & 0.095 \\
$\Delta$ NPL & 133 & 0.092 & 0.022 & 0.683 & 0.031 \\
$\Delta$ Loan & 133 & 0.051 & 0.009 & 0.663 & 0.021 \\
$\Delta G D P$ & 133 & 4.861 & -0.172 & 9.974 & 0.006 \\
Cris & 133 & 0.346 & 0 & 1 & 0.417 \\
ISm & 133 & 0.017 & -0.121 & 0.261 & 0.039 \\
Cap & 133 & 0.013 & 0.003 & 0.194 & 0.025 \\
Sig & 133 & 0.004 & -0.101 & 0.273 & 0.026 \\
Size & 133 & 8.33 & 4.731 & 16.739 & 1.045 \\
\hline
\end{tabular}

Note. LLP is the ratio of Loan loss provisions to total assets. NPL is the ratio of non-performing loans to total loans in year t. $\Delta$ Loan is the annual growth of total loans in percentage. $\triangle \mathrm{GDP}$ is the annual rate of change of Mozambican Growth Domestic Product (GDP). Cris is a dummy variable equal to one for Mozambican hidden public debt crisis (2015-2016) and zero otherwise. ISm is the ratio of earnings before interest, taxes, and LLP to total assets. Cap is the ratio of total equity to total assets. Sig is one-year ahead change in earnings before tax and provisions. Size is natural logarithm of total assets. 
A Pearson correlation matrix of the main variables used in our study is shown in Table 2. We can observe the significantly positive correlation coefficient between LLP and the ratio of non-performing loans to total loans (NPL). The negative and significant correlation coefficient between $\triangle$ GDP and LLP may imply that LLP in Mozambican banks is pro-cyclical. The coefficient ISm is significantly and positively correlated with LLP implying the potential for discretionary income-smoothing. It can be observed that the significant positive correlation between the Cap and LLP, is as predicted. In addition, the coefficients Sig and Size both are negative and statistically correlated with LLP, as predicted. Since the highest correlation coefficient is about $40 \%$ between NPL and ISm and the VIF - variance inflation factor has a maximum value of 1.39 which a mean of 1.18 , shows that the multi-collinearity does not appear to be a problem in our analysis.

Table 2. Correlation matrix of main variables

\begin{tabular}{|c|c|c|c|c|c|c|c|c|c|c|c|}
\hline Variables & LLP & LLPi,t-1 & NPL & $\Delta \mathbf{N P L}$ & $\Delta$ Loan & $\triangle G D P$ & Cris & ISm & Cap & Sig & Size \\
\hline LLP & 1.000 & & & & & & & & & & \\
\hline LLPi,t-1 & -0.003 & 1.000 & & & & & & & & & \\
\hline NPL & $0.271^{* *}$ & $0.516^{*}$ & 1.000 & & & & & & & & \\
\hline$\Delta \mathbf{N P L}$ & $0.061 * * *$ & $-0.107 * *$ & $-0.015^{*}$ & 1.000 & & & & & & & \\
\hline$\Delta$ Loan & $-0.047 * * *$ & $-0.022 * *$ & $-0.176^{* * *}$ & 0.006 & 1.000 & & & & & & \\
\hline$\Delta G D P$ & $-0.041 * * *$ & 0.079 & $-0.119 * *$ & $0.059 * *$ & $0.136^{*}$ & 1.000 & & & & & \\
\hline Cris & $-0.059 * * *$ & $-0.063 * *$ & $-0.166^{* *}$ & -0.071 & $0.037^{*}$ & $-0.039 * *$ & 1.000 & & & & \\
\hline$I S m$ & $0.085^{* * *}$ & $-0.057 * *$ & $-0.403 * * *$ & $0.254 *$ & $0.021 * *$ & $0.035^{* *}$ & $0.062 * *$ & 1.000 & & & \\
\hline Cap & $0.002 *$ & $0.021 * *$ & 0.027 & 0.011 & $-0.003^{*}$ & $-0.013 * * *$ & $-0.019 * * *$ & $-0.201^{*}$ & 1.000 & & \\
\hline Sig & $-0.006^{* * * *}$ & -0.088 & 0.030 & 0.082 & $0.063 *$ & $0.208^{* * *} *$ & $0.066^{* * *}$ & $0.043^{* *}$ & -0.046 & 1.000 & \\
\hline Size & $-0.033^{* *}$ & $-0.037 * *$ & $-0.021 * *$ & $-0.061 *$ & $-0.013 * * *$ & 0.017 & $0.008^{* *}$ & $0.004 *$ & $-0.032 *$ & 0.002 & 1.000 \\
\hline
\end{tabular}

Note. LLP is the ratio of Loan loss provisions to total assets. NPL is the ratio of non-performing loans to total loans in year t. Loan growth ( $\triangle$ Loan) is the annual growth of total loans in percentage. $\Delta$ GDP is the annual rate of change of Mozambican Growth Domestic Product (GDP). Cris is a dummy variable equal to one for Mozambican hidden public debt crisis (2015-2016) and zero otherwise. ISm is the ratio of earnings before interest, taxes, and LLP to total assets. Cap is the ratio of total equity to total assets. Sig is one-year ahead change in earnings before tax and provisions. Size is natural logarithm of total assets. A superscript of “***”, “**” and "** indicates two-tailed statistical significance at the $0.01,0.05$ and 0.10 level.

\subsection{Regression Result}

Table 3, presents the results applying the regression model. In the first column, are displayed the estimation results for equation 1.1. This model investigates the effects of the business cycle on LLP, we can observe that the coefficient $\lambda_{5}$ on $\Delta \mathrm{GDP}_{\mathrm{t}}$ variable is significantly negative (Coffic $=-0.057, \mathrm{t}$-stat $=-5.130$ ) implying the presence of cyclical components in LLP behavior. This occurs probably because provisions are triggered by the past due payments, which specifically depends on the economic dynamic system and the loan loss reserves-loan ratio. (This result is similar to Olszak et al., 2016 and Adzis et al., 2015 studies and opposes the findings of Adzis et al., 2015; Caporale et al., 2015). The coefficient $\lambda_{8}$ (Cris variable) that measure the impact of Mozambique hidden debt credit is positive and statistically significant and the coefficient $\lambda_{9}$ on the interactive dummy $\left(\triangle \mathrm{GDP}_{\mathrm{t}} * \mathrm{Cris}_{\mathrm{t}}\right)$ is negative and statistically significant (Coeffc $=-0.041$, $\mathrm{t}$-stat $\left.=-4.315\right)$. These findings imply that the macroeconomic factors had an impact in our model, on the other hand, the results suggest that the bank managers had the incentive to increase the LLP to arise loans default. These findings, maybe, are consistent with the prediction by the International Monetary Fund (2015-2016) reports that Mozambique economy was affected by Mozambique hidden debt credit and suffered from a decline in real $\Delta$ GDP during 2015 to 2016. Jointly, these findings do lend support our hypothesis H1.

The second column of Table 3, are displayed the estimated results for equation 1.2. This model investigates the effects of income smoothing through LLP. As can be observed the coefficient $\lambda_{8}$, on $\mathrm{ISm}_{\mathrm{i}, \mathrm{t}}$ on variable, is significantly positive (Coeff $=0.062$, $\mathrm{t}$-stat $=2.188$ ); suggesting the null hypothesis should not be rejected. In other words, the findings provide evidence that the bank managers are engaged in income smoothing behavior through LLP during the period of analysis, which confirms the pro-cyclical behavior of LLP. This empirical finding is in line with the conclusion of Adzis et al., 2015; 2015; Ozili, 2015 and opposes the findings of Curcio et al., 2017; Caporale et al., 2015 and Brince et al., 2015. On another hand, when we look at the coefficient $\lambda_{2}$ on $\mathrm{NPL}_{\mathrm{i}, \mathrm{t}}$ variable that postulates that non-discretionary income smoothing is significantly positive (Coeff $=0.041$, t-stat $=2.976$ ). As can be observed the bank managers are more involved in discretionary income smoothing than non-discretionary income smoothing, probably because of the poor market discipline. 
The coefficients $\lambda_{9}$ and $\lambda_{10}$ on the two interactive dummies ( $\operatorname{ISm}_{\mathrm{i}, \mathrm{t}}{ }^{*} \mathrm{Cris}_{\mathrm{t}}$ and $\mathrm{ISm}_{\mathrm{i}, \mathrm{t}}{ }^{*}$ NonCris $_{\mathrm{t}}$ respectively) are significantly positive at the $1 \%$ and $5 \%$ significance level $($ Coeff $=0.079, \mathrm{t}$-stat $=2.197$ and Coeff $=0.011$, t-stat $=2.033$ ). Thus implying that the income smoothing behavior was greater in crisis than a non-crisis period; confirms the pro-cyclical behavior of LLP. The findings still support the income-smoothing hypothesis after the inclusion of the interactive dummy variables.

The third column of Table 3, are displayed the estimated results for equation 1.3. This model investigates the effects of capital management via LLP. As can be observed the coefficient $\lambda_{9}$, on Cap $\mathrm{p}_{\mathrm{i}, \mathrm{t}}$ variable is insignificantly negative implying that capital management does not have any impact on LLP, consequently suggesting a rejection of capital management hypothesis for Mozambican commercials banks. This result is similar to Adzis et al., 2015; Caporale et al., 2015 studies and opposes the findings of Ahmed et al., 1999 and Dong et al., 2012 studies.

The column fourth of Table 3, are displayed the estimated results for equation 1.4. This model investigates the effects of signaling through LLP. As can be observed the coefficient $\lambda_{10}$ on $\mathrm{Sig}_{\mathrm{i}, \mathrm{t}}$ variable is insignificantly positive and close to zero implying that signaling does not drive the LLP consequently suggesting a rejection of signaling hypothesis through LLP for Mozambican commercials banks. This empirical finding is in line with the conclusion of Adzis et al. (2015) and Caporale et al. (2015) and opposes the findings of Olson and Zoubi (2014) and Morris et al. (2016).

Finally, the last column of Table 3, are displayed the estimated results for equation 1.4. This model investigates the effects of bank size through LLP. As can be observed the coefficient $\lambda_{8}$ on Size $\mathrm{i}_{i, \mathrm{t}}$ variable is significantly negative (Coeff $=-0.019$, t-stat $=-1.511$ ) implying that the bank's sizes have an important impact on the pro-cyclical behavior of Mozambican commercials banks. In additional, we can observe that the coefficients $\lambda_{9}$ and $\lambda_{10}$ on the two interactive dummy variables $\left(\mathrm{Size}_{\mathrm{i}, \mathrm{*}}{ }^{*} \mathrm{Cris}_{\mathrm{t}}\right.$ and $\mathrm{Size}_{\mathrm{i}, \mathrm{t}}{ }^{*} \mathrm{NonCris}_{\mathrm{t}}$ respectively) are significantly negative and significantly positive at the 5\% and $10 \%$ significance level respectively (coeff $=-0.068$, t-stat $=$ -2.043 and Coeff $=0.026$, t-stat $=2.130$, respectively). Thus implying that the bank size still has an impact on our model, specifically suggesting that the Mozambican commercials banks may be more prone to the business cycle, and thus more pro-cyclical during the Mozambican hidden debt crisis, in contrast with the non-crisis period. The sign on the size coefficient $\left(\lambda_{8}\right)$ is consistent with the prior study (Olszak et al., 2016 and Ozili, 2015).

Table 3. Baseline results from Mozambican commercials bank over the period 2010-2016 (model with bank fixed effects)

\begin{tabular}{|c|c|c|c|c|c|}
\hline & 1.1 & 1.2 & 1.3 & 1.4 & 1.5 \\
\hline \multirow[t]{2}{*}{ LLPi,t } & $0.005^{* * *}$ & $0.007 * *$ & $0.006^{* * *}$ & $0.007 *$ & $0.004 * * *$ \\
\hline & (1.020) & (1.019) & (1.028) & (1.029) & (1.201) \\
\hline \multirow[t]{2}{*}{ NPLi,t } & $0.029 * * *$ & $0.041 * * *$ & $0.030 * * *$ & $0.030 * * *$ & $0.031 * * *$ \\
\hline & (2.023) & (2.976) & (2.028) & (1.921) & (1.191) \\
\hline \multirow[t]{2}{*}{$\Delta \mathrm{NPLi}, \mathrm{t}$} & $-0.005^{*}$ & -0.004 & $-0.004^{*}$ & -0.003 & -0.003 \\
\hline & $(-0.610)$ & $(-1.177)$ & $(-1.293)$ & $(-1.972)$ & $(-1.161)$ \\
\hline \multirow[t]{2}{*}{$\Delta$ Loani,t } & $-0.003^{* * *}$ & $-0.002 * * *$ & $-0.002 * * *$ & $-0.003^{* * *}$ & $-0.002 * * *$ \\
\hline & $(-2.078)$ & $(-2.281)$ & $(-2.199)$ & $(-2.207)$ & $(-1.622)$ \\
\hline \multirow[t]{2}{*}{$\Delta$ GDPt } & $-0.057 * * *$ & $-0.068 * * *$ & $-0.058^{* * *}$ & $-0.059^{* * *}$ & $-0.067 * *$ \\
\hline & $(-5.130)$ & $(-4.997)$ & $(-5.035)$ & $(-5.182)$ & $(-4.390)$ \\
\hline \multirow[t]{2}{*}{ Crist } & $0.016^{* * *}$ & 0.015 & $0.016^{* *}$ & $0.016^{*}$ & 0.015 \\
\hline & (2.179) & $(2.012)$ & $(2.213)$ & $(2.195)$ & (3.697) \\
\hline \multirow[t]{2}{*}{$\Delta G D P t *$ Crist } & $-0.041 * * *$ & $-0.041 * * *$ & $-0.047 * * *$ & $-0.050 * * *$ & $-0.048 * * *$ \\
\hline & $(-4.315)$ & $(-3.011)$ & $(-3.619)$ & $(-4.090)$ & $(-3.399)$ \\
\hline \multirow[t]{2}{*}{ ISmi,t } & - & $0.062 * * *$ & $0.068 * * *$ & $0.054^{* *}$ & - \\
\hline & - & (2.188) & (2.026) & $(1.031)$ & . \\
\hline \multirow[t]{2}{*}{ ISmi,t*Crist } & - & $0.079 * * *$ & - & - & . \\
\hline & - & (2.197) & - & - & - \\
\hline \multirow[t]{2}{*}{ ISmi,t*NonCrist } & - & $0.011^{* *}$ & - & - & . \\
\hline & - & $(2.033)$ & - & - & - \\
\hline \multirow[t]{2}{*}{ Capi,t } & - & - & -0.019 & -0.019 & -0.018 \\
\hline & - & - & $(-0.292)$ & $(-0.292)$ & $(-0.331)$ \\
\hline
\end{tabular}




\begin{tabular}{|c|c|c|c|c|c|}
\hline \multirow[t]{2}{*}{ Capi,t* Crist } & - & - & -0.001 & - & - \\
\hline & - & - & $(-0.013)$ & - & - \\
\hline \multirow[t]{2}{*}{ Capi,t*NonCrist } & - & - & -0.001 & - & - \\
\hline & - & - & $(-0.014)$ & - & - \\
\hline \multirow[t]{2}{*}{ Sigi,t } & - & - & - & 0.000 & - \\
\hline & - & - & - & $(0.000)$ & - \\
\hline \multirow[t]{2}{*}{ Sizei,t } & - & - & - & - & $-0.019 * *$ \\
\hline & - & - & - & - & $(-1.511)$ \\
\hline \multirow[t]{2}{*}{ Sizei,t*Crist } & - & - & - & - & $-0.068 * *$ \\
\hline & - & - & - & - & $(-2.043)$ \\
\hline \multirow[t]{2}{*}{ Sizei,t*NonCrist } & - & - & - & - & $-0.026^{*}$ \\
\hline & - & - & - & - & $(-2.130)$ \\
\hline R squared & 0.4301 & 0.4309 & 0.4266 & 0.4145 & 0.4203 \\
\hline Nr .Obs. & 133 & 133 & 133 & 133 & 133 \\
\hline Nr. Banks & 19 & 19 & 19 & 19 & 19 \\
\hline
\end{tabular}

Note. LLP is the ratio of Loan loss provisions to total assets. NPL is the ratio of non-performing loans to total loans in year t. $\triangle \mathrm{NPL}$ is change in the ratio of NPL to total loans. Loan growth ( $\triangle$ Loan) is the annual growth of total loans in percentage. $\Delta \mathrm{GDP}$ is the annual rate of change of Mozambican Growth Domestic Product (GDP). Cris is a dummy variable equal to one for Mozambican hidden public debt crisis (2015-2016) and zero otherwise. $\Delta \mathrm{GDP}{ }^{*} \mathrm{Crist}$ is an interactive dummy variable between $\Delta$ GDPt and CRISt. ISm is the ratio of earnings before interest, taxes, and LLP to total assets. ISmi,t*Crist is the interactive dummy variable for income smoothing hypothesis, is equal to 1 for the years 2015-2016, 0 otherwise. ISmi,t*NonCrist is the interactive dummy variable for income smoothing hypothesis, is equal to 1 for the years 2010-2014, 0 otherwise. Cap is the ratio of total equity to total assets. Capi, ${ }^{*}$ Crist is the interactive dummy variable for capital management hypothesis, is equal to 1 for the years 2015-2016, 0 otherwise. Capi,t*NonCrist is the interactive dummy variable for capital management hypothesis, is equal to 1 for the years 2010-2014, 0 otherwise. Sig is one-year ahead change in earnings before tax and provisions. Size is natural logarithm of total assets and Sizei, $t *$ Crist is the interactive dummy variable between Sizei,t and Crist is equal to 1 for the years 2015-2016, 0 otherwise. Standard deviation of coefficient are given in parentheses and a superscript of “***”, “**” and “*” indicates two-tailed statistical significance at the $0.01,0.05$ and 0.10 levels, respectively.

In additional, we carried out additional robustness checks on our empirical results. In line with Skala, 2015 we applied the Arellano and Bover (1995) GMM difference estimator and Blundell and Bond (1998) system GMM. As can be observed in Table 4 the findings are consistent with the results of the tests in Table 3, this means that the Arellano and Bover GMM difference estimator and the Blundell-Bond system GMM results confirm the Mozambican commercial banks are pro-cyclicality, are engaged in income smoothing activity and the bank size still has an impact on our model. On the other hand, the capital management behavior and signaling activity do not drive the LLP and hence we reject these two hypotheses.

Table 4. Baseline results: Mozambican commercials bank over the period 2010-2016 (GMM estimations)

\begin{tabular}{|c|c|c|c|c|c|c|c|c|c|c|}
\hline & \multicolumn{5}{|c|}{ Arellano and Bover "GMM differences" estimation } & \multicolumn{5}{|c|}{ Blundell and Bond "GMM system" estimation } \\
\hline & 1 & 2 & 3 & 4 & 5 & 2.1 & 2.2 & 2.3 & 2.4 & 2.5 \\
\hline \multirow[t]{2}{*}{ LLPi,t } & $0.008 * *$ & 0.006 & $0.007 * *$ & $0.006 * *$ & $0.003 * * *$ & $0.013 * * *$ & $0.016^{* * * *}$ & $0.016 * * *$ & $0.019 *$ & $\overline{0.015^{* * * *}}$ \\
\hline & $(1.029)$ & $(1.221)$ & $(1.001)$ & $(1.031)$ & $(1.243)$ & $(0.063)$ & $(0.087)$ & $(0.088)$ & $(0.095)$ & $(0.093)$ \\
\hline \multirow[t]{2}{*}{ LLPi,t-1 } & 0.033 & 0.031 & 0.035 & 0.054 & 0.044 & 0.037 & 0.031 & 0.059 & 0.027 & 0.047 \\
\hline & $(0.142)$ & $(1.003)$ & $(1.997)$ & $(1.998)$ & $(1.131)$ & (1.474) & (1.045) & (1.077) & (1.879) & (2.178) \\
\hline \multirow[t]{2}{*}{ NPLi,t } & $0.048 * * *$ & $0.041 * * *$ & $0.046^{* * *} *$ & $0.048^{* * *}$ & $0.046^{* * *}$ & $0.044 * * *$ & $0.037 * * *$ & $0.045^{* * *} *$ & $0.041^{* * *} *$ & $0.040 * * *$ \\
\hline & (3.008) & (2.901) & (2.057) & $(2.981)$ & (1.909) & $(2.101)$ & (2.004) & (2.073) & $(1.990)$ & (1.163) \\
\hline \multirow[t]{2}{*}{$\Delta$ NPLi,t } & $-0.007 *$ & -0.004 & $-0.005^{*}$ & $-0.004 *$ & -0.001 & $-0.002 * *$ & $-0.003^{*}$ & $-0.004 *$ & $-0.003 *$ & -0.002 \\
\hline & $(-0.550)$ & $(-0.071)$ & $(-1.072)$ & $(-0.017)$ & $(-0.339)$ & $(-0.044)$ & $(-0.081)$ & $(-1.001)$ & $(-0.012)$ & $(-1.019)$ \\
\hline \multirow[t]{2}{*}{$\Delta$ Loani,t } & $-0.005^{* * *}$ & $-0.004 * * *$ & $-0.004 * * *$ & $-0.004^{* * *}$ & $-0.004 * * *$ & $-0.003^{* * *}$ & $-0.005^{* * * *}$ & $-0.005^{* * *}$ & $-0.004 * * *$ & $-0.006 * * *$ \\
\hline & $(-0.023)$ & $(-0.936)$ & $(-0.079)$ & $(-1.339)$ & $(-1.468)$ & $(-1.031)$ & $(-1.594)$ & $(-1.009)$ & $(-1.033)$ & $(-1.519)$ \\
\hline \multirow[t]{2}{*}{$\Delta G D P t$} & $-0.061 * * *$ & $-0.070 * * *$ & $-0.071 * * *$ & $-0.068^{* * *} *$ & $-0.072 * * *$ & $-0.074 * * *$ & $-0.074 * * *$ & $-0.097 * * *$ & $-0.083^{* * *} *$ & $-0.096 * * *$ \\
\hline & $(-5.201)$ & $(-4.872)$ & $(-5.027)$ & $(-5.176)$ & $(-4.31)$ & $(-5.028)$ & $(-5.017)$ & $(-4.033)$ & $(-4.195)$ & $(-4.447)$ \\
\hline \multirow[t]{2}{*}{ Crist } & $0.016^{* *}$ & $0.018^{* *}$ & $0.017^{*}$ & $0.017 *$ & $0.017 *$ & $0.020 * * *$ & $0.018^{* *}$ & $0.016^{* * * *}$ & $0.016^{*}$ & $0.018 * * *$ \\
\hline & $(1.221)$ & $(2.001)$ & $(2.552)$ & $(2.227)$ & $(3.341)$ & (2.089) & (2.006) & (2.117) & $(2.220)$ & $(2.071)$ \\
\hline \multirow[t]{2}{*}{$\Delta G D P t * C R I S t$} & $-0.044 * * *$ & $-0.044 * * *$ & $-0.048 * * *$ & $-0.041 * * *$ & $-0.049 * * *$ & $-0.044 * * *$ & $-0.045^{* * *}$ & $-0.049 * * *$ & $-0.046 * * *$ & $-0.041 * * *$ \\
\hline & $(-3.221)$ & $(-3.009)$ & $(-2.597)$ & $(-2.033)$ & $(-2.111)$ & $(-2.218)$ & $(-2.354)$ & $(-3.001)$ & $(-3.033)$ & $(-3.576)$ \\
\hline
\end{tabular}




\begin{tabular}{|c|c|c|c|c|c|c|c|c|c|c|}
\hline ISmi,t & - & $\begin{array}{r}0.059 * * \\
(2.007)\end{array}$ & $\begin{array}{r}0.065 * * * \\
(3.002)\end{array}$ & $\begin{array}{r}0.058 * * * \\
(2.031)\end{array}$ & - & $\begin{array}{r}0.074 * * * \\
(2.091)\end{array}$ & - & - & $\begin{array}{r}0.092 * * * \\
(2.042)\end{array}$ & - \\
\hline \multirow[t]{2}{*}{ ISmi,t*Crist } & - & $0.061 * * *$ & - & - & - & - & $0.071 * * *$ & - & - & - \\
\hline & - & $(2.805)$ & - & - & - & - & (2.069) & - & - & - \\
\hline \multirow[t]{2}{*}{ ISmi,t*NonCrist } & - & $0.012 * *$ & - & - & - & - & - & $0.012 * *$ & - & - \\
\hline & - & (2.017) & - & - & - & - & - & $(2.031)$ & - & - \\
\hline \multirow[t]{2}{*}{ Capi,t } & - & - & -0.017 & -0.017 & -0.019 & - & - & -0.018 & -0.018 & -0.019 \\
\hline & - & - & $(-0.216)$ & $(-0.216)$ & $(-0.329)$ & - & - & $(-0.217)$ & $(-0.217)$ & $(-0.330)$ \\
\hline \multirow[t]{2}{*}{ Capi,t*Crist } & - & - & -0.001 & - & - & - & - & -0.001 & - & - \\
\hline & - & - & $(-0.013)$ & - & - & - & - & $(-0.002)$ & - & - \\
\hline \multirow[t]{2}{*}{ Capi,t*NonCrist } & - & - & -0.001 & - & - & - & - & -0.001 & - & - \\
\hline & - & - & $(-0.014)$ & - & - & - & - & $(-0.010)$ & - & - \\
\hline \multirow[t]{2}{*}{ Sigi,t } & - & - & - & 0.000 & - & - & - & - & 0.000 & - \\
\hline & - & - & - & $(0.000)$ & - & - & - & - & $(0.000)$ & - \\
\hline \multirow[t]{2}{*}{ Sizei,t } & - & - & - & - & $-0.018 *$ & - & - & - & - & $-0.022 * *$ \\
\hline & - & - & - & - & $(-0.471)$ & - & - & - & - & $(-0.996)$ \\
\hline \multirow[t]{2}{*}{ Sizei,t*Crist } & - & - & - & & $-0.026 * * *$ & - & - & - & - & $-0.025 * * *$ \\
\hline & - & - & - & - & $(-1.018)$ & - & - & - & - & $(-1.099)$ \\
\hline \multirow[t]{2}{*}{ Sizei,t*NonCrist } & - & - & - & - & $0.019^{* *}$ & - & - & - & - & $0.022 * *$ \\
\hline & - & - & - & - & $(0.774)$ & - & - & - & - & $(1.001)$ \\
\hline R squared & 0.4166 & 0.3915 & 0.4077 & 0.4192 & 0.4031 & 0.4551 & 0.4401 & 0.44083 & 0.4383 & 0.4413 \\
\hline Nr .Obs. & 133 & 133 & 133 & 133 & 133 & 133 & 133 & 133 & 133 & 133 \\
\hline Nr. Banks & 19 & 19 & 19 & 19 & 19 & 19 & 19 & 19 & 19 & 19 \\
\hline \multicolumn{11}{|l|}{ AR (2) Test } \\
\hline (P-value) & 0.1937 & 0.1994 & 0.1917 & 0.2001 & 19.922 & 0.3788 & 0.3981 & 0.3992 & 0.4201 & 0.4196 \\
\hline $\begin{array}{l}\text { Hansen Test } \\
\text { (P-value) }\end{array}$ & 0.3362 & 0.3331 & 0.3395 & 0.3327 & 0.3303 & 0.4202 & 0.3997 & 0.4104 & 0.4206 & 0.4258 \\
\hline \multicolumn{11}{|l|}{ Wald Test } \\
\hline (P-value) & 0.0000 & 0.0000 & 0.0000 & 0.0000 & 0.0000 & 0.0000 & 0.0000 & 0.0000 & 0.0000 & 0.0000 \\
\hline
\end{tabular}

Note. LLP is the ratio of Loan loss provisions to total assets. LLPi,t-1 is the ratio of beginning loan loss provision to the total asset. NPL is the ratio of non-performing loans to total loans in year t. $\triangle \mathrm{NPL}$ is change in the ratio of NPL to total loans. $\Delta$ Loan is the annual growth of total loans in percentage. $\triangle$ GDP is the annual rate of change of Mozambican Growth Domestic Product (GDP). Cris is a dummy variable equal to one for Mozambican hidden public debt crisis (2015-2016) and zero otherwise. $\Delta \mathrm{GDP}{ }^{*} \mathrm{Crist}$ is an interactive dummy variable between $\triangle \mathrm{GDPt}$ and CRISt. ISm is the ratio of earnings before interest, taxes, and LLP to total assets. ISmi,t*Crist is the interactive dummy variable for income smoothing hypothesis, is equal to 1 for the years 2015-2016, 0 otherwise. ISmi,t*NonCrist is the interactive dummy variable for income smoothing hypothesis, is equal to 1 for the years 2010-2014, 0 otherwise. Cap is the ratio of total equity to total assets. Capi,t*Crist is the interactive dummy variable for capital management hypothesis, is equal to 1 for the years 2015-2016, 0 otherwise. Capi,t*NonCrist is the interactive dummy variable for capital management hypothesis, is equal to 1 for the years 2010-2014, 0 otherwise. Sig is one-year ahead change in earnings before tax and provisions. Size is natural logarithm of total assets and Sizei, ${ }^{*}$ Crist is the interactive dummy variable between Sizei,t and Crist is equal to 1 for the years 2015-2016, 0 otherwise. Standard deviation of coefficient are given in parentheses and a superscript of “***”, “**” and “*” indicates two-tailed statistical significance at the $0.01,0.05$ and 0.10 levels, respectively.

\section{Conclusion}

Starting from the hypothesis, an empirical study was developed, applying the generalized method of moments (GMM) with first differences. Our main findings can be summarized in five points. Firstly, the coefficient $\lambda_{5}$ that captured the association between $\triangle \mathrm{GDP}_{\mathrm{t}}$, and LLP was significantly positive, consistent with previous literature (Olszak et al., 2016 and Ozili, 2015) providing the evidence to lend support to the pro-cyclical behavior through LLP. In additional, during the Mozambique hidden debt credit crisis, the findings indicate that LLP of Mozambican commercials banks was more influenced by the hidden debt credit crisis. Secondly, we expected and provided evidence to lend support to the bank managers that were engaged in income smoothing behavior through LLP and they were less involved in non-discretionary income smoothing. Thirdly and fourthly, our study shows that capital management and signaling activity does not drive the LLP. Finally, we expected and provided evidence that the bank's sizes have an important impact on the pro-cyclical behavior of Mozambican commercials banks. 
This study is subject to at least one important limitation, the fact that the study concentrates on a single under-developed country may limit the possibility of generalizing the results to other contexts.

An important observation, in the Mozambican scenario, we believe that this article is the first, of the kind, to study the relationship between the determinants of LLP (the business cycle, income smoothing, capital management and signaling) in the banking sector because in our literature review there was scanty evidence about the subject. The outcome of this study suggests the use of different models to explore the same issue in future studies. On the other hand, make a comparative study between countries with different institutional arrangements and regulations.

\section{Acknowledgments}

We gratefully acknowledge the friends: Tyttayuma, Olivia Chongo, Raul, Ginho and Cardoso who helped in the collection of information. We gratefully acknowledge also to all the colleagues in the accounting and finance department of Xi'an Jiaotong University, in particular, Mr. Geoffrey Tamakloe and Daniel Bediako, who strongly criticized the article.

\section{References}

Adzis, A. A., Anuar, H. S., \& Hishamuddin, N. M. (2015). Malaysian Commercial Banks: Do Income Smoothing, Capital Management, Signaling, and Pro-Cyclicality Exist Through Loan Loss Provisions? International Journal of Economics, Finance and Management, 4, 1-9.

Ahmed, A. S., Takeda, C., \& Thomas, S. E. (1999). Bank loan-loss provisions: a reexamination of capital management, earnings management and signaling effects. Journal of Accounting and Economics, 28(1), $1-25$.

Anandarajan, A., Hasan, I., \& McCarthy, C. (2007). Use of loan loss provisions for capital, earnings management and signaling by Australian banks. Accounting \& Finance, 47, 357-379.

Arellano, M., \& Bover, O. (1995). Another look at the instrumental variables estimation of error components models. Journal of Econometrics, 68, 29-51.

Benston, G. J., \& Wall, L. D. (2005). How should banks account for loan losses? Journal of Accounting and Public Policy, 24, 81-100.

Bikker, J. A., \& Hu, H. (2002). Cyclical patterns in profits, provisions, and lending of banks and procyclicality of the new Basel capital requirements. Banca Nazionale del Lavoro Quarterly Review, 55, 143-175.

Blundell, R., \& Bond, S. (1998). Initial conditions and moment restrictions in dynamic panel data models. Journal of Econometrics, 87(1), 115-43.

Bouvatier, V., \& Lepetit, L. (2008). Banks' pro-cyclical Behavior: Does provisioning matter? Journal of International Financial Markets, Institutions and Money, 18, 513-526.

Bouvatier, V., Laetitia, L., \& Strobel, F. (2014). Bank income-smoothing, ownership concentration and the regulatory environment. Journal of Banking \& Finance, 41, 253-70. https://hal-unilim.archives-ouvertes.fr/hal-0091916674

Bryce, C., Dadoukis, A., Hall, M., Nguyen, L., \& Simper, R. (2015). An analysis of loan loss provisioning behavior in Vietnamese banking. Finance Research Letters, 14, 69-75.

Caporale, G. M., Alessi, M., Di Colli, S., \& Lopez, J. S. (2015). Loan Loss Provision: Some Empirical Evidence for Italian Banks. CESifo Working Paper Nr. 5253

Chang, R. D., Shen, W. H., \& Fang, C. J. (2008). Discretionary loan loss provisions and earnings management for the banking industry. Journal of International Business and Economics Research.

Cucinelli, D. (2015). The Impact of Non-performing Loans on Bank Lending Behavior: Evidence from Italian Banking Sector. Euroasian Journal of Business and Economics, 8(16), 59-71. https://doi.org/10.17015/ejbe.2015.016.04

Curcio, D., \& Hasan, I. (2013). Earnings and capital management and signaling: the use of loan loss provisions by European banks. The European Journal of Finance, 1-25.

Curcio, D., De Simone, A., \& Gallo, A. (2017). Financial crisis and international supervision: New evidence on the discretionary use of loan loss provisions at Euro Area commercial banks. The British Accounting Review, 49(2), 181-193.

Dong, X., Liu, J., \& Hu, B. (2012). Research on the relationship of commercial bank's loan loss provision and 
earnings management and capital management. Journal of Service Science and Management, 171-179. https://doi.org/10.4236/jssm.2012.52021

El Sood, H., A. (2012). Loan loss provisions and income smoothing in US banks pre and post the financial crisis. International Review of Financial Analysis, 25, 64-72.

Fernando, W. D. I., \& Ekanayake, E. M. N. N. (2015). Do Commercial Banks Use Loan Loss Provision to Smooth Their Income? Empirical Evidence from Sri Lanka Commercial Banks. Journal of Finance and Bank Management, 3(1), 167-179. https://dx.doi.org/10.15640/jfbm.v3n1a15

Floro, D. (2010). Loan Loss Provisioning and the Business Cycle: Does Capital Matter? Evidence from Philippine Banks. BIS Working Paper.

Fonseca, A. R., \& González, F. (2008). Cross-country determinants of bank income smoothing by managing Loan Loss Provisions. Journal of Banking \& Finance, 32(2), 217-28. https://doi.org/10.1016/j.jbankfin.2007.02.012

Jin, J., Kanagaretnam, K., \& Lobo, G. J. (2016). Discretion in bank loan loss allowance, risk taking and earnings management. Accounting and Finance. Forthcoming.

Kanagaretnam, K., Krishnan, G. V., \& Lobo, G. J. (2009). Is the market valuation of banks' Loan Loss Provision conditional on auditor reputation? Journal of Banking and Finance, 33(6), 1039-1047.

Kanagaretnam, K., Lim, C. Y., \& Lobo, G. J. (2010). Auditor reputation and earnings management: International evidence from the banking industry. Journal of Banking \& Finance, 34, 2318-2327.

Kanagaretnam, K., Lobo, G. J., \& Yang, D. H. (2005). Determinants of signaling by banks through Loan Loss Provisions. Journal of Business Research, 58, 312-320.

Kanagaretnam, K., Lobo, G., \& Yang, D. (2004). Joint tests of signaling and income smoothing through bank Loan Loss Provisions. Contemporary Accounting Research, 21, 843.884.

Kilic, E., Lobo, G. J., Ranasinghe, T., \& Sivaramakrishnan, K. (2013). The impact of SFAS 133 on income smoothing by banks through Loan Loss Provisions. Accounting Review, 88, 233-260. http://doi.org/10.2308/accr-50264

Laeven, L., \& Majnoni, G. (2003). Loan Loss Provisioning and economic slowdowns: Too much, too late? Journal of Financial Intermediation, 12(2), 178-97.

Leventis, S., Dimitropoulos, P. E., \& Anandarajan, A. (2012). Loan Loss Provisions, earnings management and capital management under IFRS: The case of EU commercial banks. Journal of Financial Services Research, 40(1-2), 103-122.

Leventis, S., Dimitropoulos, P. E., \& Anandarajan, A. (2014). Signaling by banks using Loan Loss Provisions: The case of the European Union. Journal of Economic Studies, 39(5), 604-618.

Leventis, S., Dimitropoulos, P., \& Owusu-Ansah, S. (2013). Corporate governance and accounting conservatism: Evidence from the banking industry. Corporate Governance: An International Review, 21, 264-286. https://doi.org/10.1111/corg.12015

Lobo, G. J. (2017). Accounting research in baking - A review. China Journal of Accounting Research, 10, 1-7. https://doi.org/10.1016/j.cjar.2016.09.003

Lobo, G. J., \& Yang, D. (2001). Bank Managers "Heterogeneous Decisions on Discretionary Loan Loss Provisions". Review of Quantitative Finance and Accounting, 16, 223-250.

Morris, R. D., Kang, H., \& Jie, J. (2016). The determinants and value relevance of banks' discretionary Loan Loss Provisions during the financial crisis. Journal of Contemporary Accounting \& Economics, 12(2), 176-190.

Olson, D., \& Zoubi, T. A. (2014). The determinants of loan loss and allowances for MENA banks. Journal of Islamic Accounting and Business Research, 5(1), 98-120.

Olszak, M., M. Pipien, I. K., \& Roszkowska, S. (2014). What drives heterogeneity of pro-cyclicality of Loan Loss Provisions in the EU? University of Warsaw Faculty of Management. Working Paper Series 3/2014.

Olszak, M., Pipień, M., Kowalska, I., \& Roszkowska, S. (2016). What Drives Heterogeneity of Cyclicality of Loan Loss Provisions in the EU? Journal of Financial Services Research, 51(1), 1-42.

Ozili, P. K. (2015). Loan Loss Provisioning, Income Smoothing, Signaling, Capital Management and 
Pro-cyclicality: Does IFRS Matter? Empirical Evidence from Nigeria. Mediterranean Journal of Social Science, 6(2), 224-232. https://doi.org/10.5901/mjss.2015.v6np224

Packer, F., \& Zhu, H. (2012). Loan Loss Provisioning practices of Asian banks. BIS Working Paper, No 375.

Pérez, D., Salas-Fumás, V., \& Saurina, J. (2008). Earnings and capital management in alternative Loan Loss Provision regulatory regimes. European Accounting Review, 17(3), 423-445.

Skała, D. (2015). Saving on a Rainy Day? Income Smoothing and Pro-cyclicality of Loan Loss Provisions in Central European Banks. International Finance, 18(1), 25-46. https://doi.org/10.1111/1468-2362.12058

Wahlen, J. (1994). The nature of information in commercial bank Loan Loss disclosures. Accounting Review, 69, 455-478.

\section{Copyrights}

Copyright for this article is retained by the author(s), with first publication rights granted to the journal.

This is an open-access article distributed under the terms and conditions of the Creative Commons Attribution license (http://creativecommons.org/licenses/by/4.0/). 